\title{
Nuoruusiän terveysongelmien vaikutus koulutuspolkuihin
}

\section{TERVEYDEN SOSIAALISTEN SEURAUSTEN PITKÄ JA LYHYT HISTORIA}

Vakavan sairastumisen mahdollisuus on yksi harvoista kohtaloista, joka yhdistää ihmisiä yli ajan, paikan ja yhteiskunnallisen aseman. Ajatusta voi kenties kyseenalaistaa tuomalla esille lääketieteen kehityksen tai sosioekonomisten terveyserojen esiintymisen, mutta tosiasiassa emme ole vieläkään kohdanneet yhteiskuntaa tai ihmisryhmää, jossa sairauksia ei esiintyisi lainkaan. Pitkälti aiheen universaaliuden vuoksi kertomuksia sairauksien sosiaalisista seurauksista on mahdollista löytää niin nykypäivältä kuin kaukaa historian takaa. Antiikin tutkimuksen yksi keskeisistä mysteereistä liittyy Ateenan ruttona tunnettuun kulkutautiin, jonka uskotaan vieneen mukanaan yli neljäsosan kaupunkivaltion väestöstä vuosina 430-426 ennen ajanlaskun alkua. Historiantutkimuksessa epidemiaa on pidetty merkittävänä syynä Ateenan tappiolle peloponnesolaissodassa ja sen katsotaan romahduttaneen Ateenan aseman kreikkalaisten kaupunkivaltioiden joukossa (1). Aikalaiskertomuksista erityisen huomionarvoisia ovat historioitsija Thukydideen kuvaukset, joissa kaikkialla läsnä oleva sairastumisen ja kuoleman uhka näyttävät johtaneen yleiseen moraalin rappioon. Kun elämän ei uskottu olevan tarpeeksi pitkä rikkauksista tai hyvästä maineesta nauttimiseen, ihmiset alkoivat rikkoa lakeja ja tuhlata rahojaan holtittomasti. Epidemian seurauksena näyttääkin tapahtuneen yllättävä vaurauden uusjako, jossa osa alempiin sosiaaliluokkiin kuuluneista ateenalaisista peri suuria omaisuuksia tautiin menehtyneiltä sukulaisiltaan (2).

Globaalin pandemian keskellä viittaukset antiikin ajan kulkutauteihin eivät tunnu niin kaukaa haetuilta kuin vielä joitain vuosia sitten. On kuitenkin todettava, että tyypillinen sairaudenkuva on muuttunut radikaalisti noista ajoista. Eritoten vauraissa länsimaissa kroonisia sairauksia ja mielenterveysongelmia on viimeisen vuosi- sadan aikana diagnosoitu enenevässä määrin, samalla kun käsitys sairauksiin liittyvästä äkillisestä kuolemanvaarasta on väistynyt, joskaan ei tyystin kadonnut. Kaikesta huolimatta ajatus sairauksista toimintamahdollisuuksia rajoittavina vastavoimina tuntuu edelleen yhtä ajankohtaiselta kuin mitä se oli Antiikin ruttoa käsittelevissä aikalaiskuvauksissa. Pitkäaikainen kansanedustaja Ben Zyskowicz on eri yhteyksissä kertonut sairastavansa kroonista migreeniä, joka aiheuttaa hänelle lääkityksestä huolimatta alituista lamauttavaa päänsärkyä. Hän on maininnut haastatteluissa migreeninsä syyksi siihen, ettei ole poliittisen uransa aikana tavoitellut ministeritason tehtäviä. Samasta syystä hän ilmoitti viime jouluaattona julkaistussa Helsingin Sanomien haastattelussa harkitsevansa edustakuntatyön lopettamista meneillään olevan kauden jälkeen.

Vastaavanlaiset kertomukset työikäisten ihmisten kamppailusta fyysisten sairauksien, mielenterveysongelmien tai toimintakykyä rajoittavien vammojen kanssa ovat tyypillistä nykyajan mediakuvastoa. Sen sijaan mitä nuoremmista ihmisistä on kyse, sitä helpompaa on päätyä tekemään oletus yhtäläisestä terveydestä ja toimintakyvystä. Näin on erityisesti nykyään, kun kansalliset rokotusohjelmat ovat käytännössä hävittäneet kokonaan monet entisajan lapsia ja nuoria vaivanneet vakavat infektiotaudit (3). Koulututerveyskyselyjen perusteella kuitenkin tiedämme, että yläkouluikäisistä nuorista reilulla viidesosalla on jokin lääkärin diagnosoima pitkäaikainen sairaus tai terveysongelma (4), ja vastaavanlaisiin osuuksiin on päädytty kansainvälisissä tutkimuksissa (5). Oman lukunsa tässä sairauksien kirjossa muodostavat mielenterveyden häiriöt, joita on viimeisen kolmenkymmen vuoden aikana diagnosoitu yhä enemmän ja yhä nuoremmilla. Suomalaisessa, vuosina 1987 ja 1997 syntyneitä nuoria vertailleessa kohorttitutkimuksessa havaittiin, että teini-ikäisenä saadut diagnoosit oli- 
vat lisääntyneet tytöillä 10 prosentista 15 prosenttiin ja pojilla reilusta 6 prosentista vajaaseen 9 prosenttiin (6).

Pohtiessani väitöskirjalleni aihetta havahduin siihen, kuinka vähän itse asiassa tiedämme terveysongelmien vaikutuksesta lasten ja nuorten toimintakykyyn. Erityisen niukasti tuntui olevan sellaista tutkimusta, joka pystyisi kertomaan, saavatko vakavia tai pitkäkestoisia terveysongelmia kokevat nuoret samanlaiset lähtökohdat aikuisuuteen kuin se suuri enemmistö, joka elää verrattain sairauksista vapaan kasvuiän. Tällaiset pohdinnat ovat olleet itselleni erityisen olennaisia lähtiessäni tutkimaan nuoruusiässä koettujen terveysongelmien vaikutusta koulutuspolkuihin. Ajattelen yksinkertaisesti niin, että koulutus on muodostunut yhä tärkeämmäksi nyky-yhteiskunnassa, jossa useimmat säännöllistä toimeentuloa tarjoavat työt vaativat jonkinlaista erityisosaamista. Tässä mielessä koulutuksen sujumista voi pitää tärkeänä nuorten toimintakyvyn mittarina ja koulutustasoa olennaisena hyvinvoinnin määrittäjänä.

Väitöskirjani yhteenvedossa esitän myös vaihtoehtoisen, enemmän tieteenhistoriaan nojaavan lähestymiskulman, jota pidän aiheeseen liittyvän tutkimusperinteen kannalta vähintään yhtä olennaisena. Taustoittavassa kirjallisuuskatsauksessa tuon esille, että näiden kysymysten pohtiminen tieteellisesti ei niinkään palaudu antiikin Kreikkaan vaan 1800-luvulle ja nykyisin sosiaaliepidemiologiana tunnetun alan varhaishistoriaan. Samasta tutkimusperinteestä on lähtöisin käsite terveyteen liittyvä valikoituminen koulutukseen, joka mielestäni tavoittaa kaikkein monitahoisimmin sen ilmiön, jota väitöskirjani käsittelee.

\section{TUTKIMUKSEN TAVOITTEET JA TULOKSET}

Väitöskirjani täydentää aiempaa aihetta käsittelevää tieteellistä tutkimusta erityisesti kolmesta näkökulmasta, joita käsittelen lyhyesti seuraavaksi. Ensinnäkin tutkimus tuo aiempaa monipuolisemmin esille erityyppisten terveysongelmien merkitystä koulutusurien kannalta. Siinä missä huomattava osa aiemmasta tutkimuksesta on joutunut turvautumaan laajasti saatavilla oleviin terveydentilan epäsuoriin mittareihin, kuten syntymäpaino, itseraportoitu terveys tai pituuskasvu $(7,8)$, väitöskirjassani on ollut mahdollisuus tunnistaa erityyppisiä, 10-16-vuotiaana diagnosoituja terveysongelmia erikoissairaanhoidon rekisteritietojen avulla.
Tutkimuksen tulokset osoittavat, että varhaisia mielenterveysongelmia kohdanneilla nuorilla koulutustaso jää keskimäärin matalammaksi kuin niillä, jotka eivät ole kokeneet mielenterveysongelmia. Itse asiassa nämä yhteydet ovat niin vankkoja, että ne voidaan havaita jopa samasta perheestä tulevien biologisten sisarusten välillä: kahdesta sisaruksesta se, joka on kokenut mielenterveysongelmia 10-16-vuotiaana, jää jopa kymmenen prosenttiyksikköä todennäköisemmin toisen asteen koulutuksen ulkopuolelle. Nuorten syrjäytymistä käsittelevässä yhteiskunnallisessa keskustelussa mielenterveysongelmat ja koulupudokkuus on tavattu liittää lähes määritelmällisesti toisiinsa (9). Tosiasiassa aiempi todistusaineisto on tarjonnut niukasti mahdollisuuksia arvioida, lisäävätkö mielenterveysongelmat koulutuksen ulkopuolelle jäämistä vai selittyykö näiden tekijöiden samanaikainen esiintyminen esimerkiksi sosioekonomisella huono-osaisuudella. Väitöskirjan tulosten pohjalta voidaan todeta, että mielenterveysongelmien yhteys koulutuspolkuihin on enimmäkseen riippumaton perhetaustasta.

Vaikka mielenterveysongelmien painoarvo koulutuksen määrittäjänä on erityisen keskeinen, analyysien perusteella myös tietyt fyysiset sairaudet, kuten epilepsia, synnynnäiset sydänsairaudet ja taajaan toistuvat infektiotaudit, ovat yhteydessä matalammaksi jäävään koulutustasoon. On mahdollista, että fyysisten sairauksien merkitystä on aliarvioitu aiemmissa tutkimuksissa, jotka ovat keskittyneet analysoimaan varsin kapeaa sairauksien joukkoa. Vaikka mikään yksittäinen sairaus ei ole erityisen yleinen 10-16-vuotiailla, tutkimuksen perusteella erityyppiset fyysiset ja psyykkiset terveysongelmat voivat yhdessä selittää jopa viidesosan toisen asteen koulutuksen suorittamattomuudesta.

Toinen väitöskirjaa läpileikkaava tavoite on ollut kiinnittää aiempaa kattavammin huomiota erilaisiin tapoihin, joilla varhaisen terveydentilan vaikutus koulutuspolkuihin voi käytännössä ilmentyä. Vaikka kysymys toisen asteen koulutuksen suorittamisesta on työllistymis- ja jatkoopintomahdollisuuksien kannalta erityisen olennainen, voidaan yhtä hyvin kysyä, tekevätkö terveysongelmia kokeneet nuoret erilaisia valintoja ammatillisen koulutuksen ja lukion välillä kuin muut ikäryhmäläisensä. Kysymystä pohdittaessa ei tarvitse ajatella, että jompikumpi vaihtoeh- 
doista olisi jollain tavalla arvokkaampi kuin toinen. Valinta lukion ja ammatillisen koulutuksen välillä on kuitenkin käytännössä olennainen, sillä se ennakoi voimakkaasti lopullista koulutustasoa ja koulutuksen kautta saavutettavaa ammattiasemaa. Viime vuosina yliopisto-opintonsa aloittaneista ensikertalaisista noin yhdeksällä kymmenestä on ollut pohjakoulutuksena lukiokoulutus, ja ammattikorkeakouluissakin lukion on suorittanut keskimäärin kuusi kymmenesosaa uusista opiskelijoista (10).

Aiempien tutkimusten perusteella tiedetään, että terveysongelmat ovat yhteydessä heikompaan arvosanoilla mitattavaan koulumenestykseen $(11,12)$. Tästä seuraa luontaisesti kysymys, ovatko koulutuspoluissa havaittavat erot itse asiassa vain seurausta heikommasta peruskouluajan koulumenestyksestä, joka kaventaa terveysongelmia kokeneiden nuorten mahdollisuuksia jatkaa toivomaansa toiseen asteen koulutukseen. Vaikka arvosanoihin pohjautuva yhteishaku tarjoaa puitteet tällaiselle yksiselitteiselle valikoitumisprosessille, teoriakirjallisuudessa on esitetty myös hienovaraisempi tulkinta, jonka mukaan nuoruusiän terveysongelmat saattavat johtaa stigmatisoitumisen kokemuksiin, kouluympäristöstä etääntymiseen ja madaltuneisiin koulutusodotuksiin (13). Jos toisen asteen koulutuksen ohella halutaan ymmärtää, miten varhaiset terveysongelmat heijastuvat lopulliseen koulutustasoon, täytyy koulutusta seurata pitkälle aikuisuuteen ja korkea-asteen koulutus huomioiden. Analysoitaessa eroja korkea-asteen koulutuksessa on tosin otettava huomioon, että ne voivat olla joko kokonaan tai osittain seurausta toisen asteen koulutuksessa havaituista valikoitumisprosesseista.

Tulosten perusteella varhaisnuoruuden terveysongelmat ennustavat samanaikaisesti sekä runsaampaa perusasteen koulutuksen varaan jäämistä että ammatillisen koulutuksen suorittamista lukion sijaan. Perusasteen päättötodistuksen arvosanoilla on huomionarvoinen muttei läheskään kaiken kattava merkitys näiden yhteyksien selittäjinä. Korkea-asteen koulutuksen osalta tutkimus tuo esille, että 10-16-vuotiaana koetut terveysongelmat ennustavat vähäisempää tutkinnon suorittamista niilläkin, jotka suorittavat toisen asteen koulutuksen. Toisaalta näyttää siltä, että varhaiseen terveyteen liittyvät erot korkea-asteen koulutuksen suorittamisessa tulevat suurelta osin ennakoiduiksi jo valinnassa lukion ja ammatillisen koulutuksen välillä. Poikkeuksen muodostavat mielenterveysongelmat, jotka vähentävät korkea-asteen koulutuksen suorittamista noin kuudella prosenttiyksiköllä toisen asteen linjavalinnasta riippumatta.

Kolmantena ohjaavana näkökulmana tutkimus kiinnitti huomiota sosioekonomisen perhetaustan ja terveyteen liittyvien koulutuserojen välisiin kytköksiin. Totesin edellä, että perheen sosioekonomiset tekijät eivät juurikaan näyttäisi selittävän terveysongelmien ja matalan koulutuksen välistä yhteyttä. Tämä havainto ei kuitenkaan sulje pois sitä mahdollisuutta, että varhaisten terveysongelmien sosiaaliset seuraukset voivat erota toisistaan perheen sosioekonomisen aseman mukaan. Aiemmassa tutkimuksessa on esitetty perhetaustan merkitykselle kaksi päinvastaista tulkintaa $(14,15)$. Kompensatoristen resurssien näkökulmasta voitaisiin ajatella, että korkeasti koulutettujen vanhempien lapsilla on monia kouluttautumista tukevia kulttuurisia ja materiaalisia resursseja, jotka saattavat suojata terveysongelmien haitalliselta vaikutukselta. Vastakkaisen tulkinnan mukaan terveysongelmat saattavat nimenomaan estää hyödyntämästä tällaisia resursseja täydessä mitassa ja johtavat siten suurempiin koulutustason madaltumisiin korkeasti koulutetuissa perheissä.

Ajatusketjua voi jatkaa ja esittää, että terveysongelmat saattavat myös toimia selittävänä linkkinä koulutustason ylisukupolvisessa periytymisessä vanhemmilta lapsille. Tällainen kehityskulku on mahdollinen, jos terveysongelmat ovat yleisempiä matalasti koulutettujen perheiden lapsilla ja jos ne lisäksi vaikuttavat haitallisesti kouluttautumiseen. Ensimmäinen oletuksista saa varovaista tukea sosioekonomisten terveyserojen tutkimusperinteestä (16), kun taas jälkimmäinen koskettaa tämän tutkimuksen ydinkysymystä.

Oletukset perhetaustan ja terveysvalikoitumisen välisistä kytköksistä saavat väitöskirjassa pienimuotoisen vahvistuksen. Näyttää siltä, että korkeasti koulutettujen vanhempien lapsilla toisen asteen koulutus jää muita harvemmin kesken mielenterveysongelmien seurauksena. Lisäksi terveysongelmat näyttäisivät selittävän noin kymmenen prosenttia siitä erosta, joka havaitaan toisen asteen koulutuksen suorittamisessa matalasti ja korkeasti koulutettujen vanhempien lapsilla. Näistä osatuloksista huolimatta vanhempien 
matala koulutus ja nuoruusiän terveysongelmat näyttäytyvät pääosin toisistaan erillisinä lyhyeksi jäävän koulutusuran taustatekijöinä.

\section{LOPUKSI}

Tutkimuksen tekemisessä yksi kiehtova piirre on, ettei tutkija voi koskaan olla täysin varma tutkimuksensa pitkäaikaisesta vastaanotosta. Ajan saatossa tutkimuksesta voi kehittyä alaa uudelleen määrittelevä klassikko tai se voi muuttua varoittavaksi esimerkiksi entisajan harhaluuloista. Yhtä lailla tutkimus voi päätyä osaksi pakollisten siteerattavien joukkoa, johon harva on todellisuudessa ehtinyt vuosikausiin perehtyä, tai - kuten todennäköistä - se voi vaipua saman tien unholaan, kuten niin monille tutkimusjulkaisuille käy tutkimuksen massatuotannon aikakaudella.

Mikään ei kuitenkaan estä toivomasta, ja omalta osaltani toivon, että tutkimukseni auttaa näkemään varhaisen terveyden sosiaaliset seuraukset kiinnostavana tutkimuskohteena ja yhteiskuntapoliittisesti merkittävänä kysymyksenä. Tämä edellyttää toki sen hyväksymistä, että yhteiskunnalliset ongelmakohdat voivat joskus palautua yksilöllisiin eroihin, vaikka näiden erojen syyt, saati niiden seuraukset, eivät johtuisikaan yksilön omista valinnoista.

Rekisteritutkimukselle ominaiseen tapaan väitöskirjani tarjoaa niukasti vastauksia siihen kysymykseen, mitkä tekijät lopulta selittävät terveysongelmien yhteyttä matalaksi jäävään koulutukseen. Positiivisten vastausten puutteessa tutkimus tuo esille kaksi hyödyllistä negaatiota. Koska tiedämme nyt, että ilmiö on huomattavilta osin riippumaton perhetaustasta ja koulumenestyksestä, ei perinteisillä sosiaalipoliittisilla toimilla tai pelkästään arvosanoihin keskittymällä luultavasti saavuteta toivotunlaisia voittoja. Valistuneena arvauksena esittäisin, että vaikuttavimmat ratkaisut löytyvät terveysongelmien sosiaalisten seurausten vahvemmasta tiedostamisesta opintojen ohjauksessa, oppilashuollossa ja nuorisopsykiatriassa. Erityisen suuri merkitys saattaa olla näiden palveluiden onnistuneella yhteispelillä, jotta terveysongelmia kokeneen nuoren koulunkäyntiä voidaan tukea kokonaisvaltaisesti. Tänä vuonna voimaan astuva oppivelvollisuuden korotus 18 ikävuoteen ei luultavasti yksin riitä ratkaisemaan terveysvalikoitumisen ongelmaa, sillä tulosten perusteella ilmiö ei typisty pelkästään kysymykseen siitä, kuka jatkaa ja kuka ei jatka toisen asteen koulutukseen. Riittävästi resursoituna uudistus voi kuitenkin tarjota ainutlaatuisen mahdollisuuden pehmentää perusasteen ja toisen asteen välistä siirtymää, joka on tässä ja muissa tutkimuksissa osoittautunut erityisen haavoittuvaiseksi.

\section{LÄHTEET:}

(1) Soupious, MA. Impact of the plague in Ancient Greece. Infect Dis Clin North Am 2004;18:4551. doi: 10.1016/S0891-5520(03)00101-6

(2) Thukydides. The History of the Peloponnesian War. Project Gutenberg 2009. Luettu 4.6.2021. https://www.gutenberg.org/files/7142/7142h/7142-h.htm

(3) Lantto, M, Renko, M, Uhari, M. Trends in childhood mortality from 1969 to 2004 in Finland. Acta Pediatr 2008;97:1024-1029. doi: 10.1111/j.1651-2227.2008.00856.x

(4) Terveyden ja hyvinvoinnin laitos. Lasten ja nuorten hyvinvointi - Kouluterveyskysely 2019. Luettu 10.6.2021. https://thl.fi/f/tilastot-ja-data/ tilastot-aiheittain/lapset-nuoret-ja-perheet/lastenja-nuorten-hyvinvointi-kouluterveyskysely-2019

(5) Van Der Lee, JH, Mokkink, LB, Grootenhuis, MA, Heymans, HS, Offringa, M. Definitions and measurement of chronic health conditions in childhood: a systematic review. Jama 2007;297:2741-2751. doi: 10.1001/jama.297.24.2741

(6) Gyllenberg D, Marttila M, Sund R, JokirantaOlkoniemi E, Sourander A, Gissler M, Ristikari $\mathrm{T}$. Temporal changes in the incidence of treated psychiatric and neurodevelopmental disorders during adolescence: an analysis of two national Finnish birth cohorts. Lancet Psychiatry 2018:5:227-236. doi: 10.1016/S22150366(18)30038-5

(7) Hale, DR, Bevilacqua L, Viner RM. Adolescent health and adult education and employment: a systematic review. Pediatrics 2015;136:128-140. doi: 10.1542/peds.2014-2105

(8) Suhrcke, M, de Paz Nieves, C. The impact of health and health behaviours on educational outcomes in high-income countries: a review of the evidence. Kööpenhamina: World Health Organization; 2011.

(9) Juppi, P. Pahoinvoivia uhreja, turvallisuusuhkia ja taloudellisia taakkoja. Nuorten syrjäytymisen tulkintakehykset suomalaisessa uutismediassa. Janus 2011;19:200-220

(10) Opetushallitus. Vipunen - Opetushallinnon tilastopalvelu. Luettu 10.6.2021. https://vipunen.fi/fi-fi

(11) Crump, C, Rivera, D, London, R, Landau, M, Erlendson, B, Rodriguez, E. Chronic health conditions and school performance among children and youth. Ann Epidemiol 2013;23:179-184.

doi: 10.1016/j.annepidem.2013.01.001 
(12) Ding, W, Lehrer, SF, Rosenquist, JN, AudrainMcGovern, J. The impact of poor health on academic performance: new evidence using genetic markers. J Health Econ 2009;28:578597. doi: 10.1016/j.jhealeco.2008.11.006

(13) Lynch JL, von Hippel PT. An education gradient in health, a health gradient in education, or a confounded gradient in both? Soc Sci Med 2016;154:18-27.

doi: 10.1016/j.socscimed.2016.02.029

(14) Jackson MI. Understanding links between adolescent health and educational attainment. Demography 2009;46:671-694. doi:10.1353/ dem.0.0078

(15) Jackson, MI. Cumulative inequality in child health and academic achievement. J Health Soc Behav 2015;56:262-280. doi: 10.1177/0022146515581857

(16) Viner RM, Ozer EM, Denny S, Marmot M, Resnick M, Fatusi A, Currie C. Adolescence and the social determinants of health. Lancet 2012;379:1641-52.

doi: 10.1016/S0140-6736(12)60149-4

\author{
JANne MikKonen \\ Valtiotieteiden tohtori \\ Helsingin yliopisto
}

Valtiotieteiden maisteri Janne Mikkosen väitöskirja "The Educational Consequences of Adolescent Health Problems" tarkastettiin Helsingin yliopiston valtiotieteellisessä tiedekunnassa 14.6.2021. Vastaväittäjänä toimi apulaisprofessori Elina Kilpi-Jakonen Turun yliopistosta ja kustoksena professori Pekka Martikainen Helsingin yliopistosta. 